\title{
DESAIN MOZAIK PADA BINGKAI BELAH KETUPAT DENGAN MOTIF FRAKTAL DAN KONSTRUKSINYA PADA MATLAB
}

\author{
Miftahur Roifah \\ Pendidikan Guru Pendidikan Anak Usia Dini, Fakultas Ilmu Pendidikan, \\ IKIP PGRI Jember \\ miftahurroifah@ikipjember.ac.id
}

\begin{abstract}
:
Mosaics are the artistic creations made from pieces of shape which are then arranged and affixed to a plane and designed using a tiling pattern with a basic pattern of geometric objects.. The progress of science and technology enables innovations especially after the invention of computers, one of which is fractals. Fractals are widely used in computer graphics to create amazing shapes. Mosaic designs can also be made with fractal concepts. The aims of this research are to get the procedure for mosaic design on circle and rhombus frames by hexagon and Pinwheel tiling with fractal motif. The research method covered the design of basic form for mosaic in the interior of circle and rhombus. Furthermore fill the basic form of mosaic wuth some fractal motif. The results of this research are the procedure to design some basic form of mosaic with the following steps. Firstly, divide the interior area of the circle and rhombus. Secondly, identify the symmetrical basic form. Thirdly, design the basic form of mosaic. Whereas procedure to fill the basic form of mosaic with fractal motif with the following steps. Firstly, choose the specify fractal motif. Secondly, fill the motif into each basic form. Thirdly, fill motif on the background. Then the final step is programmed the mosaics with Matlab 7 software.
\end{abstract}

Keywords: mosaic, Pinwheel tiling, rhombus, fractal.

\section{PENDAHULUAN}

Mozaik merupakan suatu karya seni rupa yang terbentuk dari kepingankepingan kecil yang disusun dan ditempelkan pada sebuah bidang dengan mengombinasikan bentuk dan warna. Mozaik dapat dibentuk dari potonganpotongan kertas, batu kecil-kecil, kepingan kulit telur, dan masih banyak lagi bahan yang dapat digunakan. Mozaik banyak ditemukan di sekitar kita, seperti pada wallpaper, lantai, pot bunga, lukisan, batik, kerajinan gypsum bahkan pada kaca ventilasi. Mozaik dirancang menggunakan pola-pola pengubinan dengan bingkai dasar berupa benda geometris seperti persegi, lingkaran, belah ketupat, dan lain sebagainya.

Burkholder (2015) menyebutkan bahwa pengubinan Pinwheel merupakan pengubinan yang ditemukan oleh John H. Conway dan Charles Radin. Pungubinan ini pada awalnya berupa segitiga siku-siku yang kemudian pada iterasi ke-1 ubin tunggal ini dibagi menjadi lima segitiga kongruen yang sebangun dengan segitiga awal. Selanjutnya pada iterasi ke-2, kelima segitiga tersebut masing-masing dibagi menjadi lima segitiga kongruen yang sebangun seperti pada iterasi ke-1. Begitu seterusnya sampai iterasi ke- $n$ (Nuh, 2014).

Kemajuan Ilmu Pengetahuan dan Teknologi (IPTEK) terutama setelah ditemukannya komputer memungkinkan terjadinya inovasi. Salah satu cabang matematika yang berkembang cukup pesat dengan adanya komputer adalah 
geometri fractal (Bourke, 1991). Dalam Addison (1997) disebutkan beberapa bentuk matematis yang merupakan fraktal, seperti segitiga Sierpinski, Koch snowflake, kurva Naga, himpunan Mandelbrot (As'ari, Tohir, Valentino, Imron, \& Taufiq, 2017; As'ari, Tohir, Valentino, Imron, \& Taufik, 2016; Mandelbrot, 1983), himpunan Julia, dan masih banyak lagi. Fraktal banyak dipakai dalam komputer grafik untuk menciptakan bentuk-bentuk menakjubkan karena keindahannya. Desain pola motif mozaikpun dapat dibuat menggunakan konsep fraktal, bahkan dengan perkembangan IPTEK dapat diciptakan aplikasi yang mempermudah untuk membuat sebuah desain mozaik.

Sebelumnya, Murihani, Kusno, \& Susanto (2012) telah dilakukan penelitian tentang modelisasi mozaik dengan jenis dan macam pola terfokus pada bingkai persegi dan lingkaran (Widiastuti, 2014). Namun isiannya masih berupa potongan garis, lingkaran, elips, atau benda geometri lainnya sehingga variasi isian yang didapat kurang beragam. Selain itu, telah dilakukan penelitian tentang modelisasi mozaik pada ubin Penrose (Rosyadi, Kusno, \& Santoso, 2012). Hasilnya ditekankan pada pembentukan bangun-bangun simetris untuk mengisi seluruh ubin dan hanya diberi warna-warna sebagai pembeda tanpa adanya pemberian motif isian. Oleh sebab itu, tujuan pertama dari penelitian ini adalah mendapatkan prosedur modelisasi bangun dasar mozaik pada interior belah ketupat dengan pola ubin Pinwheel. Sedangkan tujuan kedua adalah mendapatkan prosedur pengisian bangun dasar mozaik dengan motif berupa fraktal. Dan yang terakhir adalah programasi modelisasi mozaik dalam software Matlab 7 untuk memudahkan dalam membuat desain mozaik.

\section{METODE PENELITIAN}

Dalam penelitian modelisasi mozaik ini dibagi menjadi tiga tahapan. Tahapan pertama adalah menetapkan data penelitian yaitu ubin Pinwheel yang dilanjutkan dengan merefleksikan ubin Pinwheel tersebut terhadap sumbu vertikal, kemudian hasilnya direfleksikan kembali terhadap sumbu horizontal sehingga membentuk sebuah bangun belah ketupat. Tahapan kedua adalah mengidentifikasi bentuk bangun-bangun dasar simetris pada bingkai belah ketupat yang dilanjutkan dengan modelisasi bangun dasar mozaik. Tahapan ketiga adalah dilakukan pengisian bangun dasar mozaik dengan motif berupa fraktal segitiga Sierpinski, Koch snowflake, kurva Naga, himpunan Mandelbrot, dan himpunan Julia. Selanjutnya tahapan terakhir adalah visualisasi model mozaik menggunakan software Matlab 7.

\section{HASIL DAN PEMBAHASAN}

\section{Pembagian Interior Belah Ketupat}

Diberikan sebuah ubin Pinwheel iterasi ke-2 dengan titik-titik sudut $A(0,2 a)$, $B(0,0)$, dan $C(a, 0)$. Ubin Pinwheel pada interior belah ketupat, didapatkan melalui proses refleksi segitiga $A B C$ terhadap sumbu $Y$, dengan demikian didapatkan sebuah segitiga sama kaki $C^{\prime} A C$. Selanjutnya dilakukan proses refleksi pada segitiga $C^{\prime} A C$ terhadap sumbu $X$ sehingga didapatkan bentuk belah ketupat $A C A^{\prime} C^{\prime}$ dengan interior berisikan pengubinan Pinwheel (Gambar 1).

Alifmatika: Jurnal Pendidikan dan Pembelajaran Matematika, Desember 2019, Vol. 1, No. 1 


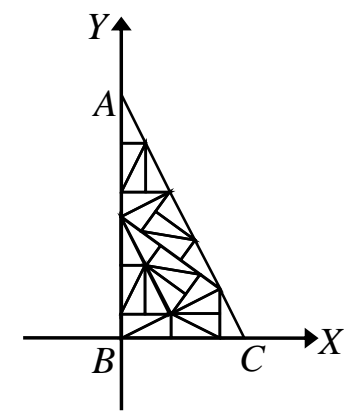

(a)

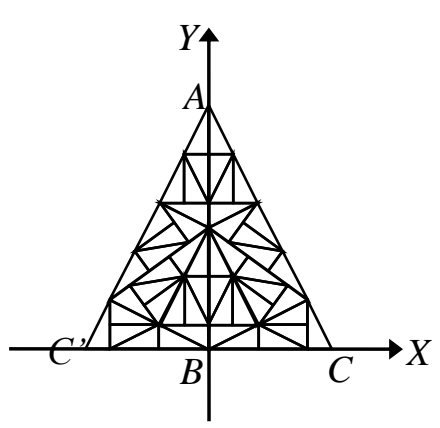

(b)

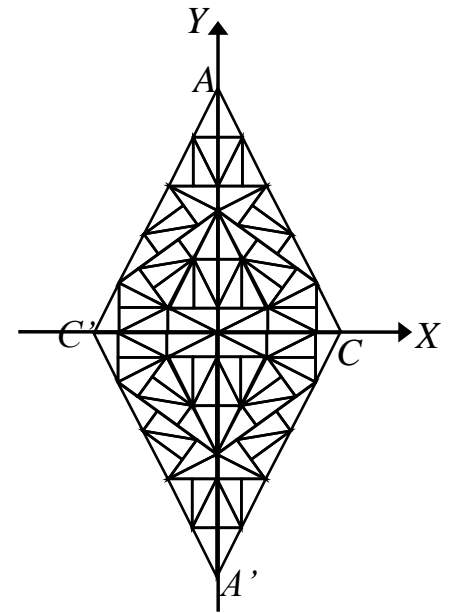

(c)

Gambar 1 Pembagian daerah belah ketupat

\section{Modelisasi Bangun Dasar Mozaik}

\section{1) Identifikasi Bangun Dasar Simetris}

Pada ubin Pinwheel, didapatkan bangun-bangun dasar dengan bentuk menyerupai bentuk gunung, anak panah, diamon, dan layang-layang. Selanjutnya bangun-bangun ini disebut sebagai bangun dasar Gunung, Anak Panah, Diamon, dan Layang-layang yang ditunjukkan pada Gambar 2.

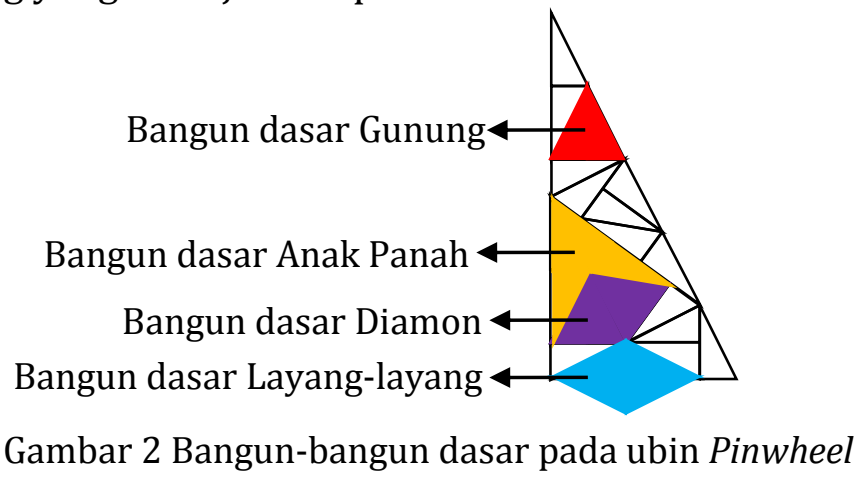

\section{2) Model Bangun Dasar Mozaik}

a. Model Bangun Dasar Sejenis

- Pandang sumbu X dan Y sebagai sumbu simetri.

- Isikan bangun-bangun dasar dengan ketentuan sebagai berikut.

- Untuk model penuh, dapat dipilih bangun dasar Gunung.

○ Untuk model tidak penuh, dapat dipilih bangun dasar Layang-layang.

- Refleksikan tiap benda dasar terhadap sumbu Y, kemudian hasilnya direfleksikan terhadap sumbu X.

- Warnai latar bingkai dengan satu warna, misalnya abu-abu. 

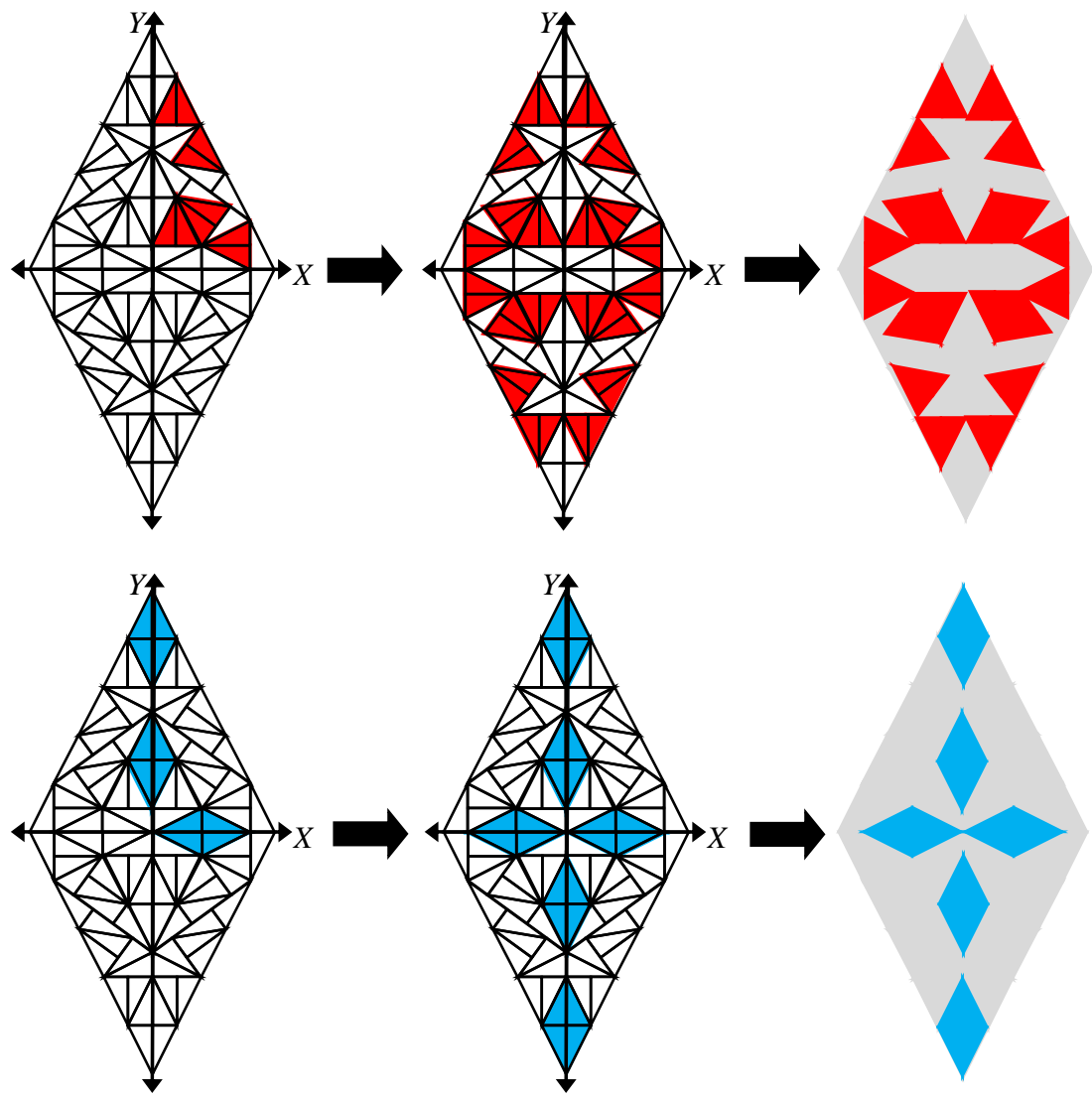

Gambar 3 Model bangun dasar sejenis

\section{b. Model Bangun Dasar Lengkap}

- Pandang sumbu X dan Y sebagai sumbu simetri.

- Isikan semua jenis bangun dasar dengan bentuk penuh pada ubin Pinwheel yang telah diidentifikasi sebelumnya.

- Refleksikan tiap benda dasar terhadap sumbu Y, kemudian hasilnya direfleksikan terhadap sumbu X.

- Warnai latar bingkai dengan satu warna, misalnya abu-abu.

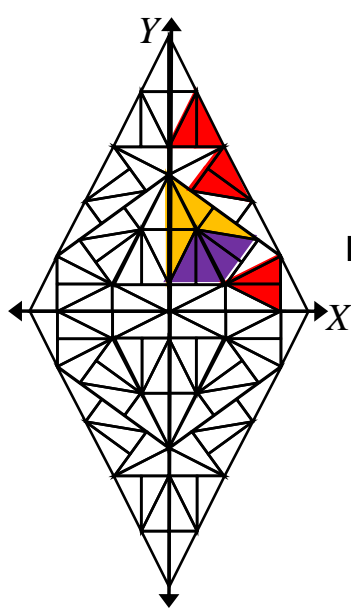

(a)

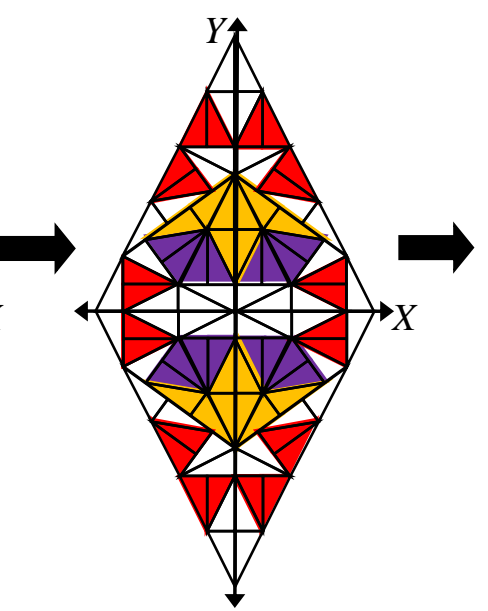

(b)

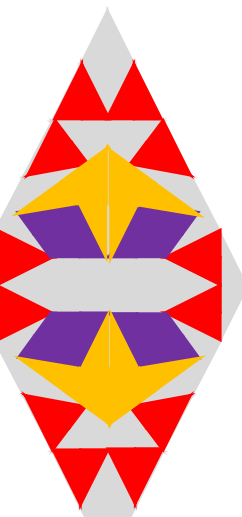

Gambar 4 Model bangun dasar lengkap

Alifmatika: Jurnal Pendidikan dan Pembelajaran Matematika, Desember 2019, Vol. 1, No. 1 


\section{Miftahur Roifah}

\section{c. Model Bangun Dasar Campuran}

- Pandang sumbu X dan Ysebagai sumbu simetri.

- Dapat dipilih diantara 4 jenis bentuk bangun dasar pada ubin Pinwheel yang telah diidentifikasi.

- Refleksikan tiap benda dasar terhadap sumbu Y, kemudian hasilnya direfleksikan terhadap sumbu X.

- Warnai latar bingkai dengan satu warna, misalnya abu-abu.

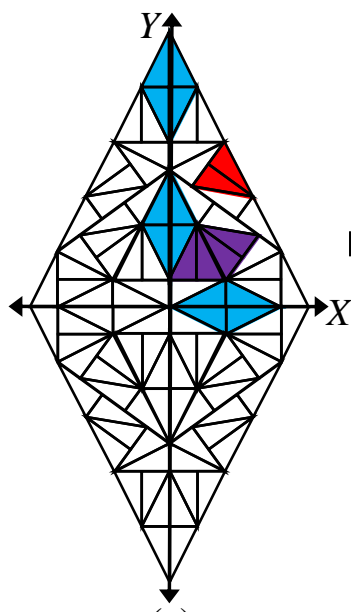

(a)

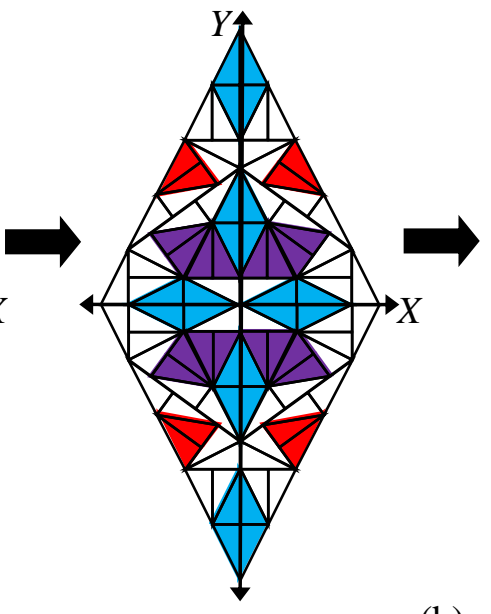

(b)

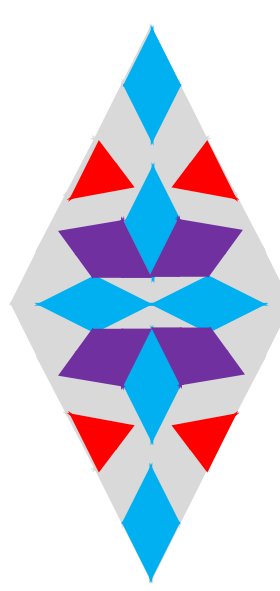

Gambar 5 Model bangun dasar campuran

\section{Pengisian Model Bangun Dasar Mozaik dengan Motif Fraktal}

\section{1) Motif Tunggal}

Dasar yang digunakan adalah adanya 4 macam bentuk bangun dasar pada bingkai kemudian diberi motif dengan fraktal yang sesuai bentuknya (Gambar 6).

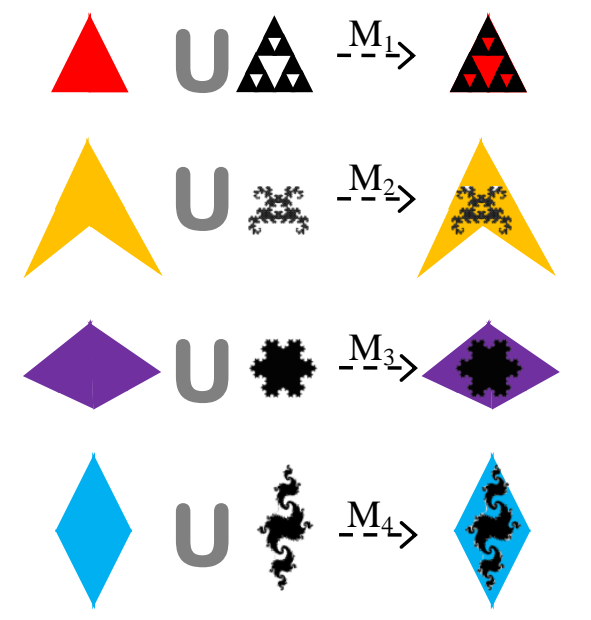

Gambar 6 Motif tunggal pada bangun dasar

Langkah-langkahnya sebagai berikut.

- Diberikan sebuah model bangun dasar mozaik.

Alifmatika: Jurnal Pendidikan dan Pembelajaran Matematika, Desember 2019, Vol. 1, No. 1 
- Isikan motif fraktal, dapat dipilih diantara 4 jenis motif M1, M2, M3, dan M4, kemudian refleksikan terhadap sumbu Y dan hasilnya refleksikan terhadap sumbu X.

- Warnai latar bingkai dengan satu warna, misalnya abu-abu.

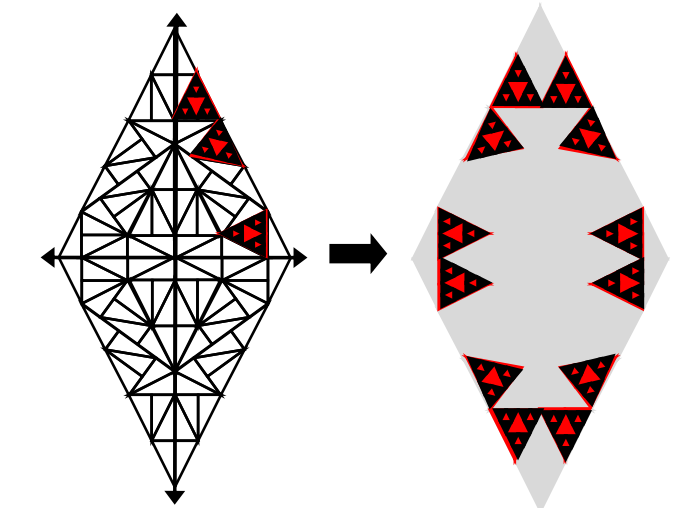

Gambar 7 Model bangun dasar motif tunggal

\section{2) Motif Campuran}

Merupakan pengembangan dari motif tunggal dengan menambahkan isian pada daerah latar, dengan langkah sebagai berikut.

- Diberikan sebuah bingkai belah ketupat.

- Isi segitiga atas bingkai dengan segitiga Sierpinski kemudian refleksikan terhadap sumbu X.

- Isikan bangun-bangun dasar.

- Isi setiap bangun dasar dengan motif fraktal.
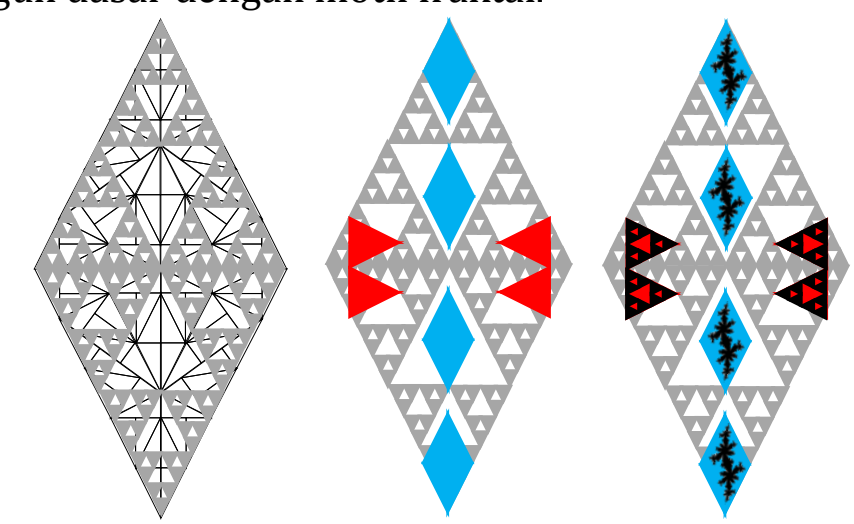

Gambar 8 Motif campuran pada bingkai belah ketupat

\section{Programasi pada software Matlab 7}

\section{1) Bingkai Belah Ketupat}

\section{figure (2);}

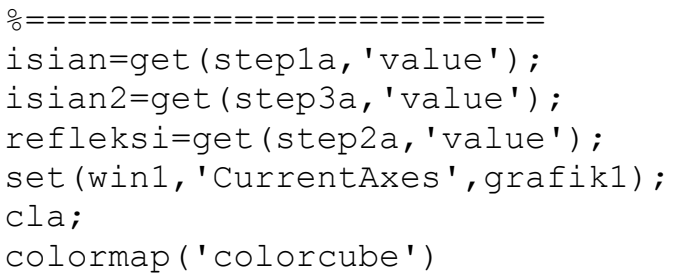

Alifmatika: Jurnal Pendidikan dan Pembelajaran Matematika, Desember 2019, Vol. 1, No. 1 


\section{Miftahur Roifah}

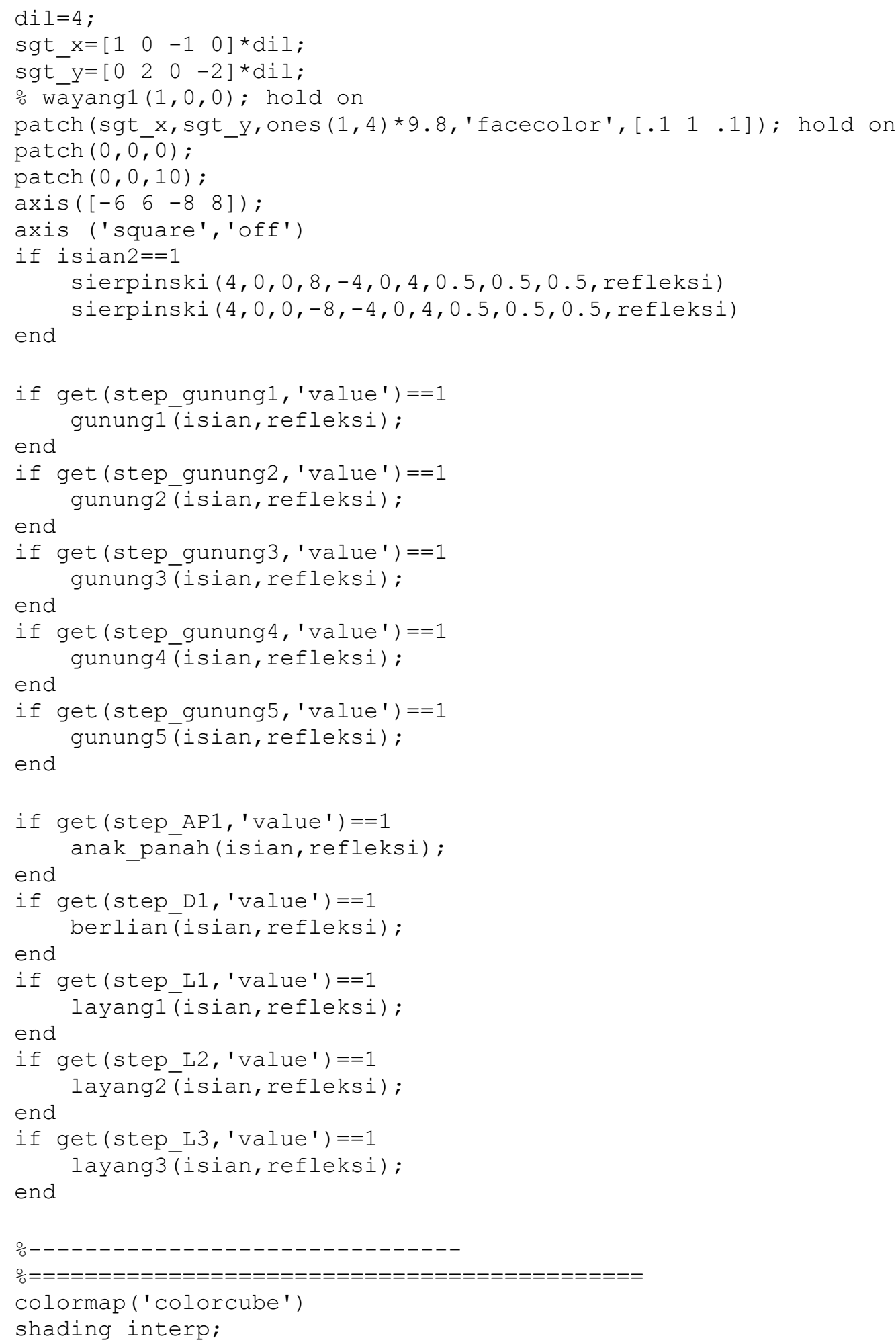

\section{2) Bangun Dasar Mozaik Bingkai Belah Ketupat}

$\frac{\circ}{\circ}=======$
$\circ$ figure (2) ;

set([step1 step2 step3],'value',0); 
Desain Mozaik Pada Bingkai Belah Ketupat dengan Motif...

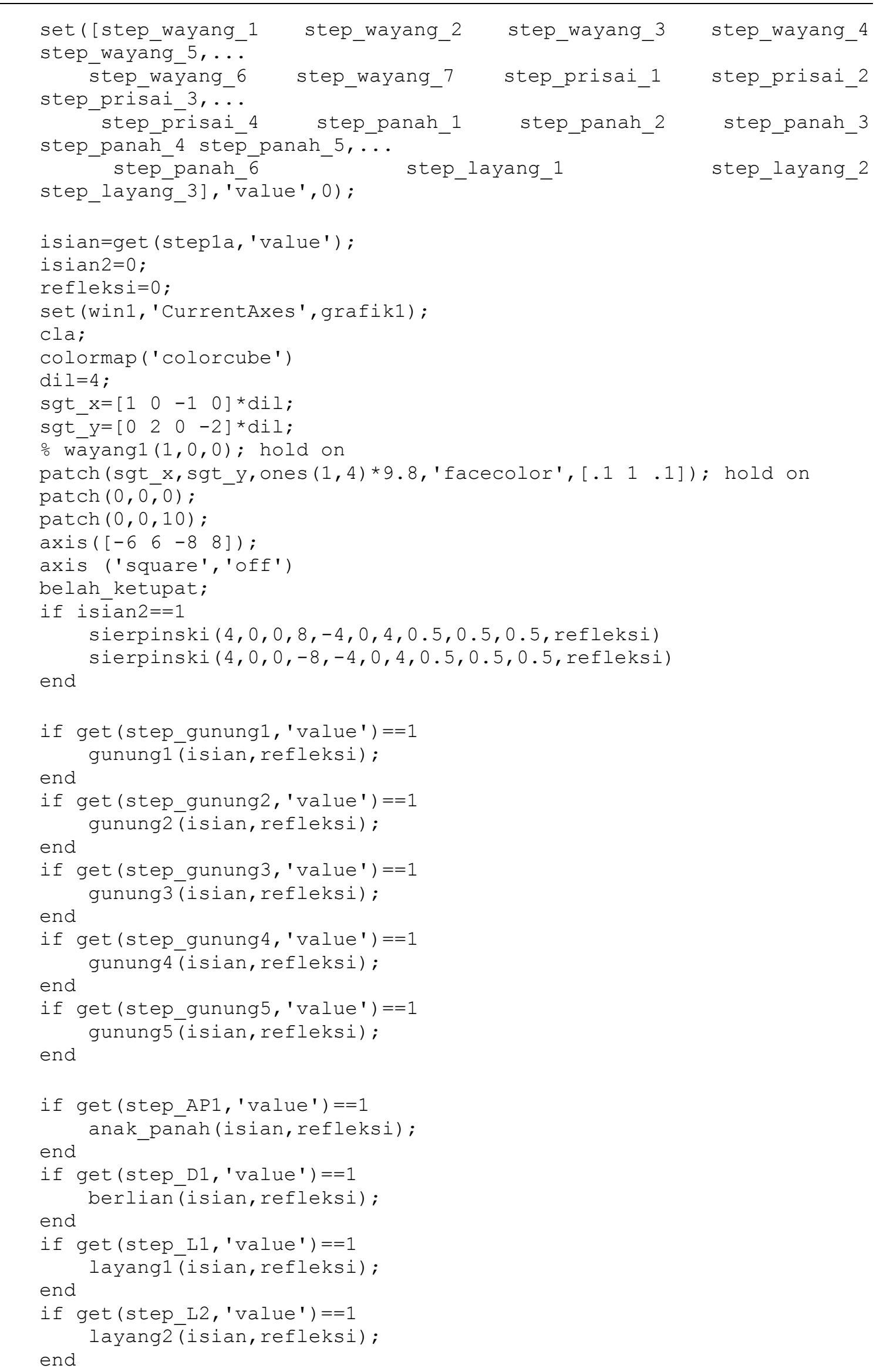

Alifmatika: Jurnal Pendidikan dan Pembelajaran Matematika, Desember 2019, Vol. 1, No. 1 


\section{Miftahur Roifah}

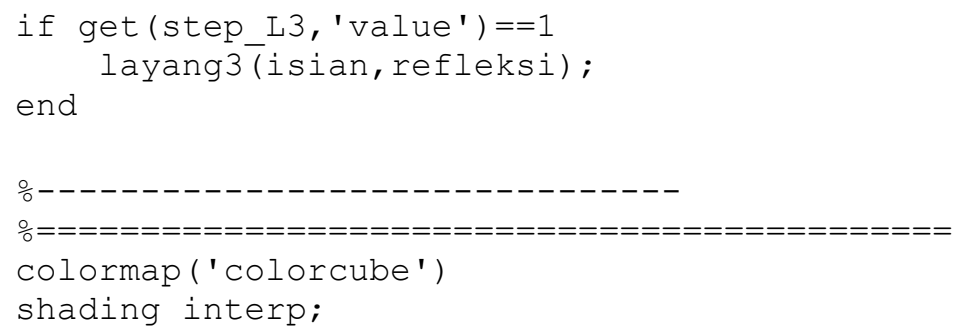

\section{3) GUI Modelisai Bangun Dasar Mozaik dengan Motif Fraktal}

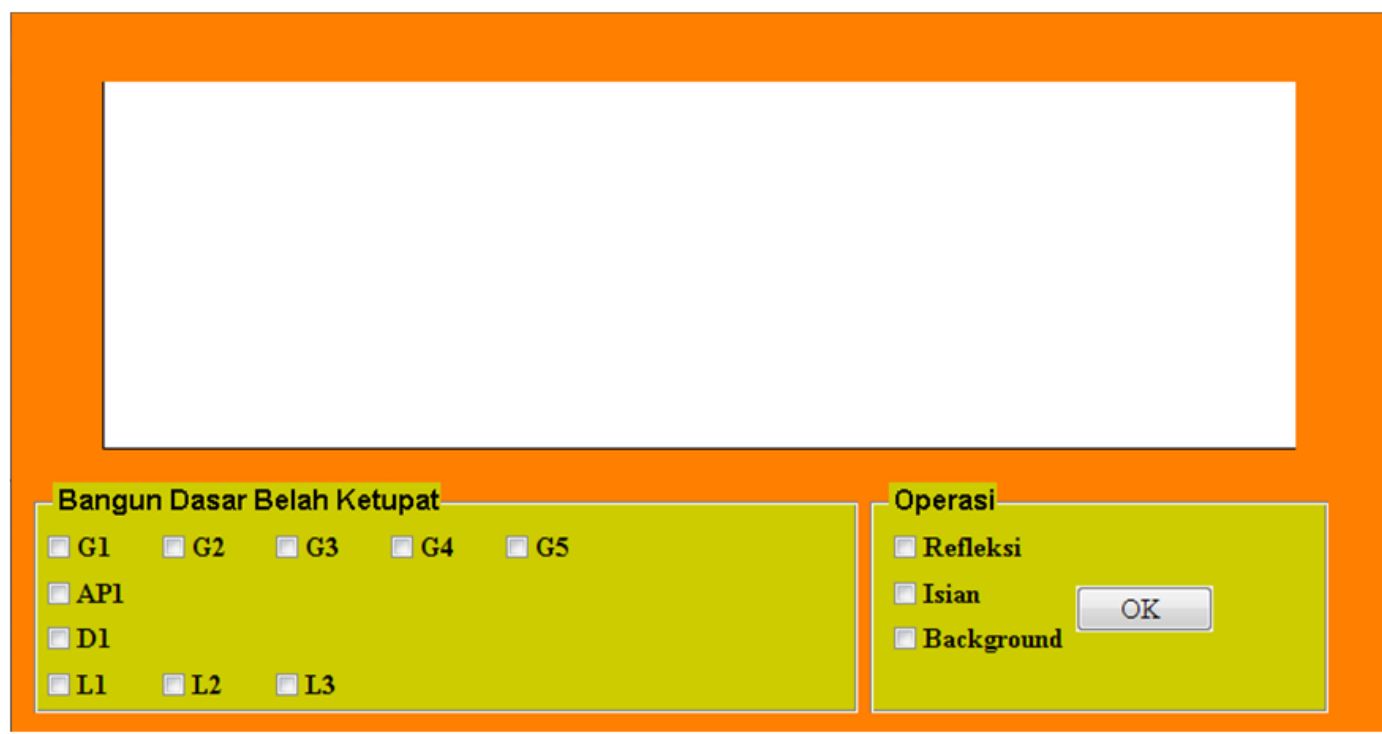

\section{4) Contoh Desain Mozaik menggunakan GUI Matlab 7}

Langkah-langkahnya sebagai berikut:

- Pilih beberapa bangun dasar sesuai selera dengan cara mencentang checkbox yang tersedia.

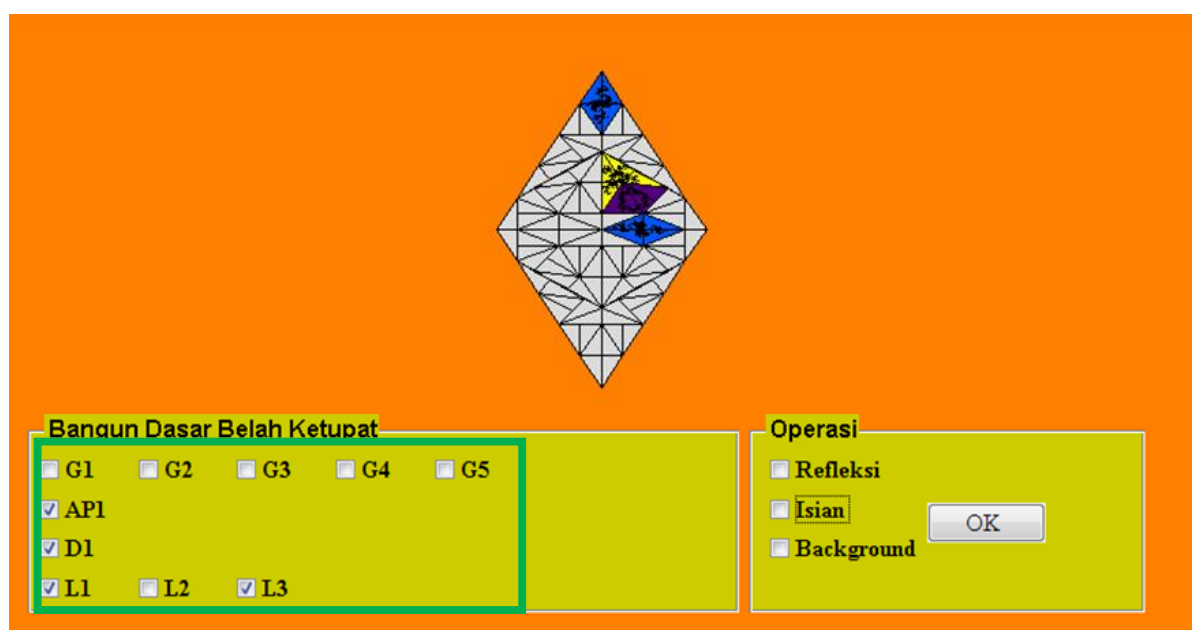

- Pilih jenis operasi yang diinginkan.

Alifmatika: Jurnal Pendidikan dan Pembelajaran Matematika, Desember 2019, Vol. 1, No. 1 


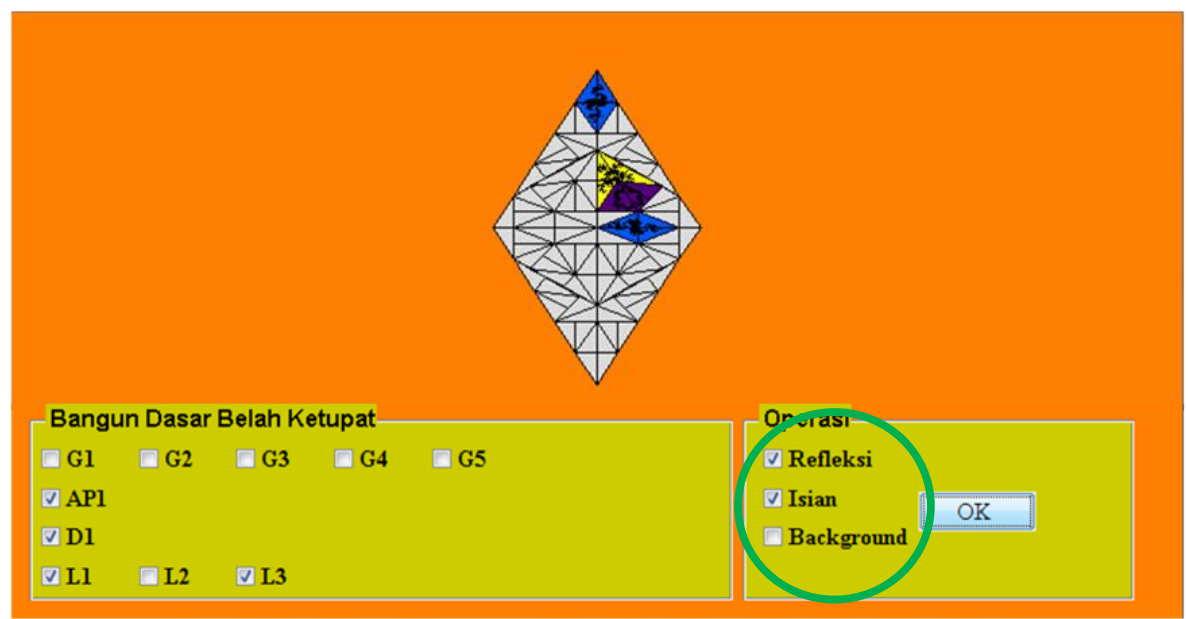

- Tekan tombol OK, dan hasilnya ditunjukkan pada gambar berikut.

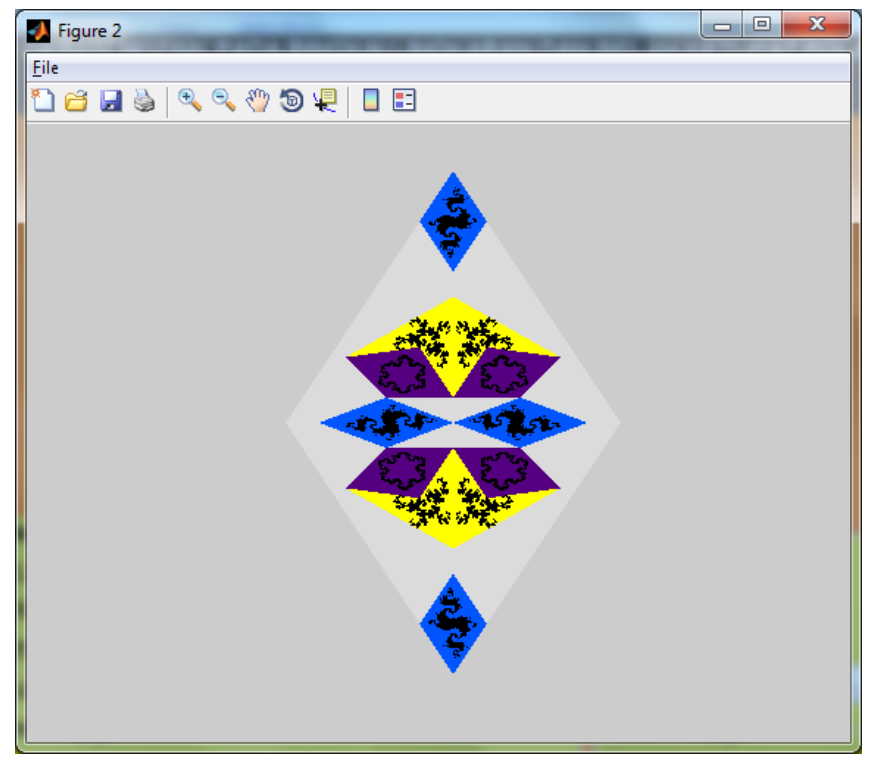

\section{KESIMPULAN}

Berdasarkan hasil dan pembahasan didapatkan untuk mendesain beragam bentuk model bangun dasar mozaik pada bingkai belah ketupat dapat dilakukan dengan langkah-langkah sebagai berikut. Pertama, mencacah daerah interior bingkai belah ketupat. Kedua, mengidentifikasi bangun-bangun geometri dasar simetris. Ketiga, menetapkan pilihan bangun dasar, yaitu: (a) memilih 2 bentuk bangun dasar, (b) merefleksikan tiap bangun dasar, dan (c) memberikan warna pada latar sehingga menghasilkan model bangun dasar yang berkarakter simetris. Sedangkan untuk mengisi model bangun dasar hasil perlakuan sebelumnya, prosedurnya sebagai berikut. Pertama, menetapkan motif fraktal tertentu yang sesuai dengan bentuk bangun dasar. Kedua, mengisikan motif tersebut pada setiap bangun dasar. Ketiga, memberikan motif pada bidang latar yang tidak terisi bangun dasar dengan motif tertentu sehingga menghasilkan model mozaik utuh yang bercorak dan variatif.

Alifmatika: Jurnal Pendidikan dan Pembelajaran Matematika, Desember 2019, Vol. 1, No. 1 


\section{Miftahur Roifah}

Saran dari penulis untuk penelitian selanjutnya adalah menggunakan bingkai benda geometri lainnya seperti segienam dan segidelapan atau bingkai dengan gabungan dua benda geometri. Selain itu penggunaan ubin Pinwheel tidak hanya terbatas pada iterasi kedua, melainkan dapat dilakukan pada iterasi lebih lanjut, serta dapat ditawarkan motif fraktal lain yang lebih bervariasi untuk mengisi model bangun dasar mozaik.

\section{Daftar Pustaka}

Addison, P. S. (1997). Fractals and chaos: an illustrated course. CRC Press.

As'ari, A. R., Tohir, M., Valentino, E., Imron, Z., \& Taufik, I. (2016). Matematika SMP/MTs Kelas VII. Jakarta: Kementrian Pendidikan dan Kebudayaan Republik Indonesia.

As'ari, A. R., Tohir, M., Valentino, E., Imron, Z., \& Taufiq, I. (2017). Buku Guru Matematika (Revisi). Jakarta: Pusat Kurikulum dan Perbukuan, Balitbang, Kemendikbud.

Bourke, P. (1991). An introduction to fractals. Noongard: The University of Western of Australia, Consulta, 5.

Burkholder, D. G. (2017). Unexpected Beauty Hidden in Radin-Conway's Pinwheel Tiling. Bridges Baltimore 2015: Mathematics, Music, Art, Architecture, Culture, 383-386.

Mandelbrot, B. B. (1983). The fractal geometry of nature (Vol. 173). WH freeman New York.

Murihani, E., Kusno, K., \& Susanto, K. A. (2012). Desain Mozaik Pada Interior Persegi Berkarakter Barisan Geometri. KadikmA, 3(3).

Nuh, M. (2014). Buku guru matematika SMP/MTs kelas VIII (Kurikulum 2013). Jakarta: Kementerian Pendidikan dan Kebudayaan.

Rosyadi, I., Kusno, K., \& Santoso, K. A. (2012). Desain Motif Mozaik pada Reguler Decagon Berbasis Golden Triangle. KadikmA, 3(3).

Widiastuti, D. (2014). Rancang Bangun Mozaik Ubin Bingkai Dasar Lingkaran dan Persegi Motif Poligon, Lingkaran dan Elips. In Tesis. Jember: Fakultas Matematika dan Ilmu Pengetahuan Alam Universitas Jember. 